\title{
INFLUENCE OF THERMOMECHANICAL TREATMENT ON THE GRAIN-GROWTH BEHAVIOUR OF NEW Fe-Al BASED ALLOYS WITH FINE $\mathrm{Al}_{2} \mathrm{O}_{3}$ PRECIPITATES
}

\author{
VPLIV TERMOMEHANSKE OBDELAVE FeAl ZLITIN S FINIMI \\ $\mathrm{Al}_{2} \mathrm{O}_{3}$ IZLOČKI NA RAST ZRN
}

\author{
Omid Khalaj', Bohuslav Mašek ${ }^{1}$, Hana Jirková1, Dagmar Bublíková1, \\ Jiří Svoboda ${ }^{2}$ \\ ${ }^{1}$ University of West Bohemia, Regional Technology Institute, Univerzitní 22, 30614 Pilsen, Czech Republic \\ 2Institute of Physics of Materials, Academy of Sciences of the Czech Republic, Žižkova 22, 616 62 Brno, Czech Republic \\ svobj@ipm.cz \\ Prejem rokopisa - received: 2016-07-20; sprejem za objavo - accepted for publication: 2017-04-20
}

doi:10.17222/mit.2016.232

\begin{abstract}
To obtain the superior-high-temperature creep strength, a transformation of a fine-grained structure to large grains due to abnormal grain growth or recrystallization is an important process in oxide-dispersion-strengthened (ODS) alloys. The processing of steel is enabled with powder metallurgy, which utilizes powders consisting of a Fe-Al metal matrix with a large O content, prepared with mechanical alloying, and their hot consolidation due to rolling. The thermomechanical characteristics of new ODS alloys with a Fe-Al matrix are investigated in terms of the changes in the grain-size distribution. The recrystallization and grain growth were quantified after heating up to $1200{ }^{\circ} \mathrm{C}$, which is the typical consolidation temperature for standard nanostructured ferritic steels. The results show that new ODS alloys are significantly affected by the thermomechanical treatment leading to microstructural changes. Recrystallization is mostly affected by decreasing the deformation and increasing the holding time, which leads to a growth of the grain size.
\end{abstract}

Keywords: grain growth, ODS alloys, steel, $\mathrm{Fe}-\mathrm{Al}, \mathrm{Al}_{2} \mathrm{O}_{3}$

Da bi pridobili najvišjo temperaturo moči lezenja, je transformacija drobnozrnate strukture v večja zrna ali celo v abnormalno velika oziroma rekristalizacija pomemben proces pri zlitinah, ojačanih z oksidno disperzijo (angl. ODS). Obdelava jekla je omogočena $\mathrm{z}$ metalurgijo $\mathrm{v}$ prahu, ki pomaga prahom, ki vsebujejo metalno matrico Fe-Al z veliko vsebnostjo kisika, pripravljeno $\mathrm{z}$ mehanskim legiranjem in njihovo vročo konsolidacijo pri valjanju. Termomehanske karakteristike novih ODS-zlitin s Fe-Al matrico so bile preiskovane, ker je prišlo do sprememb v velikosti porazdelitve zrn. Rekristalizacija in rast zrn sta bili ovrednoteni po segretju do $1200{ }^{\circ} \mathrm{C}$, ki je tipična temperatura konsolidacije za nanostrukturirana feritna jekla. Rezultati kažejo, da na ODS-zlitine zelo vpliva termomehanska obdelava, ki pripelje do sprememb v mikrostrukturi. Na rekristalizacijo največkrat vpliva deformacija in povečanje časa zadržanosti, ki povzroči rast velikost zrn.

Ključne besede: rast zrn, ODS-zlitine, jeklo, $\mathrm{Fe}-\mathrm{Al}, \mathrm{Al}_{2} \mathrm{O}_{3}$

\section{INTRODUCTION}

Historically, ODS alloys have been employed to improve high-temperature mechanical properties. In 1910, the first utilization of an oxide dispersion was reported by W. D. Coolidge. Using the classical powder metallurgy, a tungsten-based alloy reinforced with thorium oxides was developed to impede high-temperature grain growth and therefore increase the life span of a tungsten-filament lamp. ${ }^{1}$ After this first development, several other applications with various metallic matrices such as aluminium or nickel were implemented over the decades. A notable improvement in the field was made by J. S. Benjamin at the International Nickel Company (INCO) laboratory: he proposed a new process based on high-energy-milling powder metallurgy - later called mechanical alloying. ${ }^{2}$ This process was introduced to obtain a fine and homogeneous oxide dispersion within a nickel matrix. Its aim was to produce high-temperatureresistant materials for gas-turbine applications. ${ }^{3}$
Currently, mechanical alloying is still considered to be the most effective process for obtaining fine and homogeneously distributed particles. The volume fraction of dispersed spherical oxides (usually $\mathrm{Y}_{2} \mathrm{O}_{3}$ ) is typically below $1 \%$ and the oxides typically have a mean size of 5-30 nm. The mechanically alloyed powder is then consolidated at high temperatures and pressures to produce the bulk material in the form of a bar or tube stock. Subsequently, different thermomechanical treatments are applied to optimize its microstructure and mechanical properties.

Oxides are much more resistant to coarsening in the coarse-grained ferrite than the $\gamma$ '-precipitates in superalloys, and the limiting temperature for a long-term operation is between $1000{ }^{\circ} \mathrm{C}$ and $1100{ }^{\circ} \mathrm{C}$ when the mean size of oxides is $20-30 \mathrm{~nm}$. This clearly indicates that oxides are extremely stable and the microstructural stability of ODS alloys is much higher than that of nickel-based superalloys. However, a loss of mechanical properties due to the coarsening of oxides was also 
O. KHALAJ et al.: INFLUENCE OF THERMOMECHANICAL TREATMENT ON THE GRAIN-GROWTH BEHAVIOUR ...

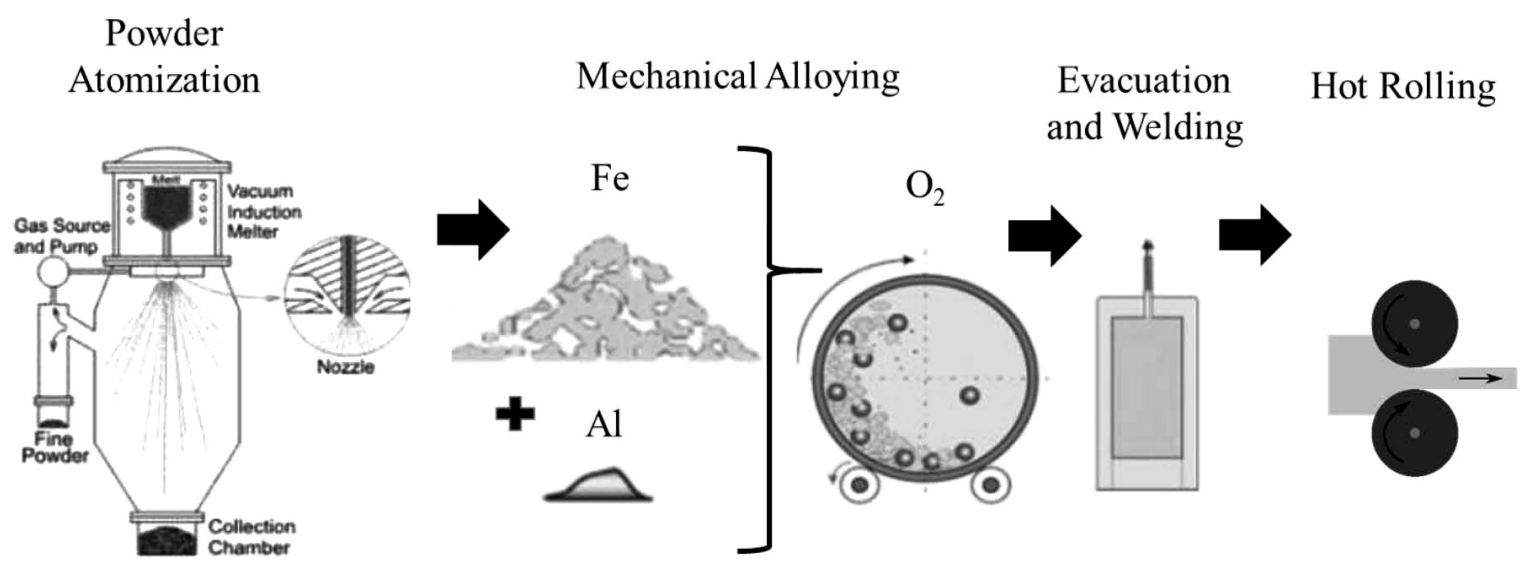

Figure 1: Material-preparation process

observed in fine-grained ODS steels at temperatures of about $800{ }^{\circ} \mathrm{C}$ for the systems with an extremely fine oxide dispersion (about $5 \mathrm{~nm}$ ). ${ }^{4}$ Thus, the size of oxides as well as the grain size are also important for the stability of the microstructure - coarser oxides are much more stable than fine ones, which is in line with the cubic law for coarsening kinetics.

In the consolidation step, the processing temperatures are critical in order to retain the nanocrystalline structure generated during the mechanical alloying and to impede the particle coarsening and grain growth. ${ }^{5-9}$ The Ni- and F-based ODS alloys rely on the formation of slowly growing and strongly adherent chromium and aluminium scales for their high temperature oxidation/corrosion resistance. In the present study, the ODS alloys consist of a ferritic $\mathrm{Fe}-\mathrm{Al}$ matrix strengthened with about $4 \%$ volume fraction of $\mathrm{Al}_{2} \mathrm{O}_{3}$ particles. ${ }^{10-15} \mathrm{In}$ order to obtain a more detailed insight into these new groups of materials, this paper will concentrate on both the general microstructure and mechanical properties of ODS steels, the phenomenon of recrystallization and the related microstructural evolutions.

\section{EXPERIMENTAL PART}

\subsection{Material preparation}

The classical processing route used to produce $\mathrm{Fe}-\mathrm{Al}$ based alloys with fine $\mathrm{Al}_{2} \mathrm{O}_{3}$ precipitates is highly dependent on powder metallurgy (Figure 1). The first step of the elaboration is the mechanical alloying of powders consisting of Fe-11 w/\% Al matrix (90w/\% Fe and $10 w / \% \mathrm{Al}$ ) and $1 \mathrm{w} / \%$ of $\mathrm{O}_{2}$ in gas, which is absorbed, in a low-energy ball mill developed by the authors, enabling evacuation and filling with oxygen. It has two steel containers (each holding 24 L) and each container is filled with 80 steel balls with a diameter of $40 \mathrm{~mm}$. The revolution speed varies between 20-75 $\min ^{-1}$. However, the speed for our research was kept constant $\left(75 \mathrm{~min}^{-1}\right)$ for all the material preparations.

This step allows the powder to be forced into a solid solution. The milled powder is then deposited into a steel container with a diameter of $70 \mathrm{~mm}$, evacuated (degassed) and sealed by welding. The steel container is then heated up to a temperature of $750{ }^{\circ} \mathrm{C}$ and rolled in a hot rolling mill to a thickness of $20 \mathrm{~mm}$ in the first rolling step, then heated up to a temperature of $900{ }^{\circ} \mathrm{C}$ and rolled to a thickness of $8 \mathrm{~mm}$ in the second step. A 6-mm-thick sheet of the ODS alloy covered on both sides with a 1-mm-thick scale from the rolling container was produced in this way. Afterwards, the specimens were cut with a water jet (Figure 5).

Eight types of material were used in this research as described in Table 1. They are all based on a Fe-10w/\% Al ferritic matrix with different particle sizes and $4 \%$ volume fraction of $\mathrm{Al}_{2} \mathrm{O}_{3}$.

$\mathrm{Al}_{2} \mathrm{O}_{3}$ powder was added to prepare the composite; fine oxides in the ODS alloys were obtained with the internal oxidation during mechanical alloying and precipitated during hot consolidation. It should be noted that in the case of Material 1 , the $\mathrm{Al}_{2} \mathrm{O}_{3}$ particles were added, but in all the other materials, oxides were produced due to internal oxidation as shown in Figure 1. Different sizes of the oxides in ODS steels are due to different heat treatments after hot rolling. SEM observations indicated several inhomogeneities due to the material sticking to the walls of the milling container during mechanical alloying.

Table 1: Material parameters

\begin{tabular}{|c|c|c|l|c|c|}
\hline $\begin{array}{c}\text { Material } \\
\text { No. }\end{array}$ & $\begin{array}{c}\text { Material } \\
\text { type }\end{array}$ & $\begin{array}{c}\text { Milling } \\
\text { time } \\
\text { (hours) }\end{array}$ & $\begin{array}{c}\text { Ferritic } \\
\text { matrix }\end{array}$ & $\begin{array}{c}\text { Vol.\% } \\
\text { of } \\
\mathrm{Al}_{2} \mathrm{O}_{3}\end{array}$ & $\begin{array}{c}\text { Typical } \\
\text { particle } \\
\text { size } \\
\text { (nm) }\end{array}$ \\
\hline 1 & ODS Alloy & 100 & Fe10wt\%Al & 10 & 300 \\
\hline 2 & ODS Alloy & 100 & Fe10wt\%Al & 6 & $50-200$ \\
\hline 3 & ODS Alloy & 150 & Fe10wt\%Al & 6 & $50-150$ \\
\hline 4 & ODS Alloy & 200 & Fe10wt\%Al & 6 & $30-150$ \\
\hline 5 & ODS Alloy & 245 & Fe10wt\%Al & 7 & $20-50$ \\
\hline $6 *$ & ODS Alloy & 245 & Fe10wt\%Al & 7 & $20-50$ \\
\hline $7^{*}$ & ODS Alloy & 245 & Fe10wt\%Al & 7 & $20-50$ \\
\hline $8^{*}$ & ODS Alloy & 245 & Fe10wt\%Al & 7 & $20-50$ \\
\hline
\end{tabular}

* Different rolling conditions 
O. KHALAJ et al.: INFLUENCE OF THERMOMECHANICAL TREATMENT ON THE GRAIN-GROWTH BEHAVIOUR ...

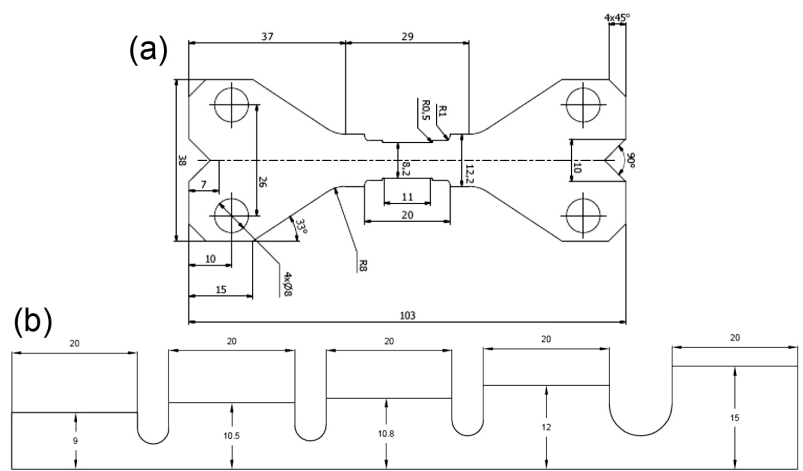

Figure 2: Specimen dimensions in mm: a) type 1, b) type 2

These inhomogeneities can also influence the mechanical properties of the material, but the mechanical alloying process is steadily optimized with respect to the homogeneity of the materials.

\subsection{Specimen preparation}

Two specimen types (Figure 2) were selected from several examples, which exhibited the most homogeneous temperature fields for specimen type 1 and simplicity of tests for specimen type 2 . Specimen type 1 was chosen from six types of specimen shapes with different active parts in the middle. All the samples were carefully monitored using a thermal camera to see how the temperature field is distributed within the active part when heated up to $1200{ }^{\circ} \mathrm{C}$. So, regarding the results, specimen type 1 (5a) has the best homogeneity regarding the temperature distribution. On the other hand, specimen type 2 is designed to have four different deformations $(5,8,20$ and 50) \% at the same time. The shortest part $(9 \mathrm{~mm})$ is designed to have no deformation during the pressing and the rest have appropriate values of deformation. This specimen is held in a hydraulic
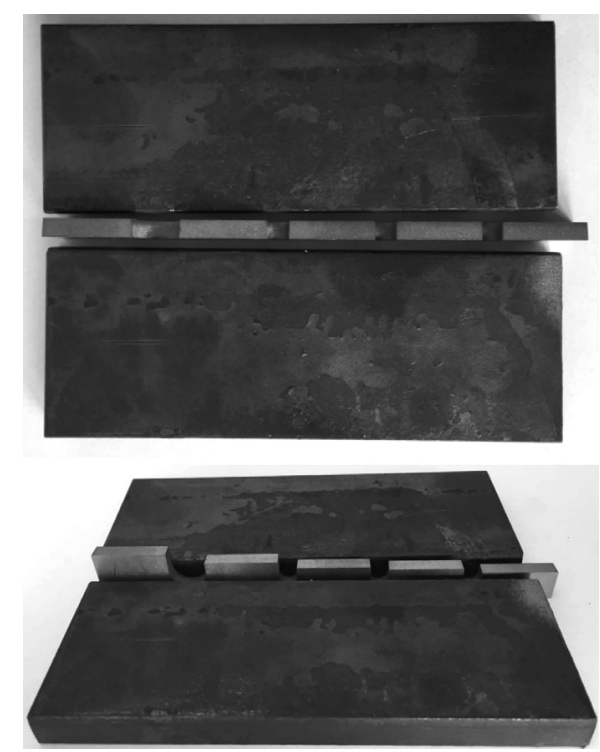

Figure 3: Positions of specimens between holding plates

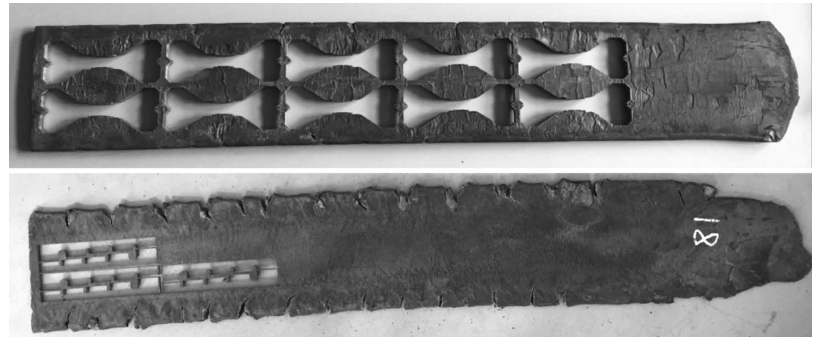

Figure 4: Positions of specimens on a rolled semi-product: a) type 1, b) type 2

forging press with two positioning side plates $(10 \mathrm{~mm}$ thick) (Figure 3) in order not to apply more deformation than required. The prepared containers were annealed at $1000{ }^{\circ} \mathrm{C}$ over $16 \mathrm{~h}$. After normal cooling at room temperature, all the specimens were cut by a water-jet machine in the longitudinal direction (Figure 4) and then all the specimens were removed from the steel containers. After grinding, the thickness of the specimens was approximately $6 \mathrm{~mm}$.

\subsection{Testing equipment}

In order to speed up the tests, a hydraulic forging press (Figure 5) was used to apply four different deformations at the same time on the type- 2 specimens. Also, in order to investigate the thermomechanical treatment of the specimens, a servo-hydraulic MTS thermomechanical simulator (Figure 6) was used, which allows various temperature-deformation paths to be run in order to find the conditions leading to, e.g., the most effective grain coarsening due to recrystallization. The thermo-

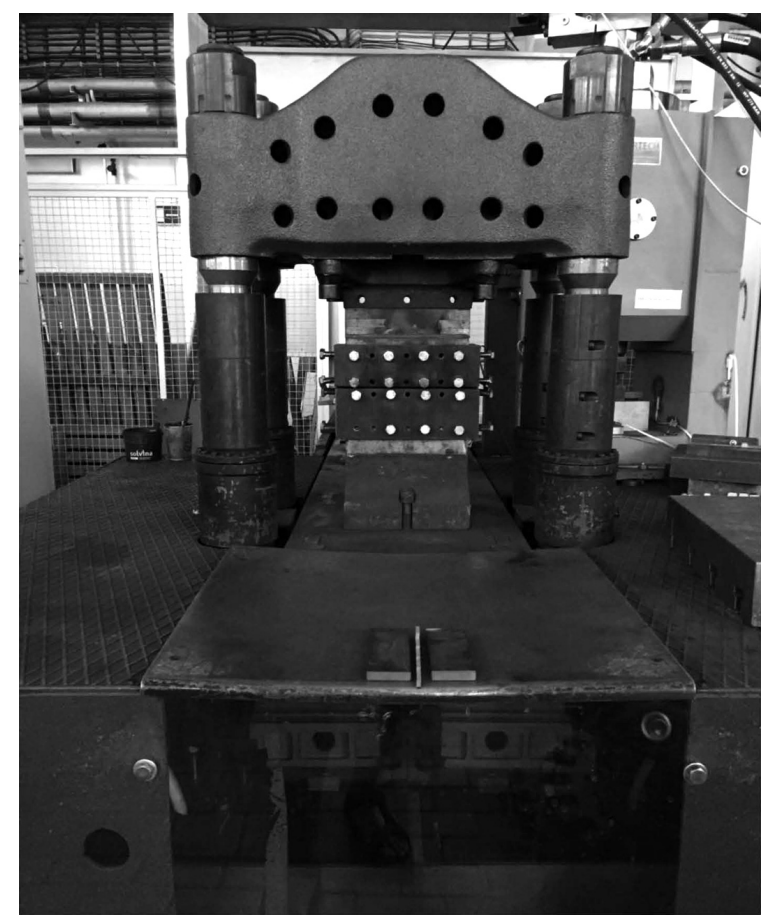

Figure 5: Hydraulic forging press 


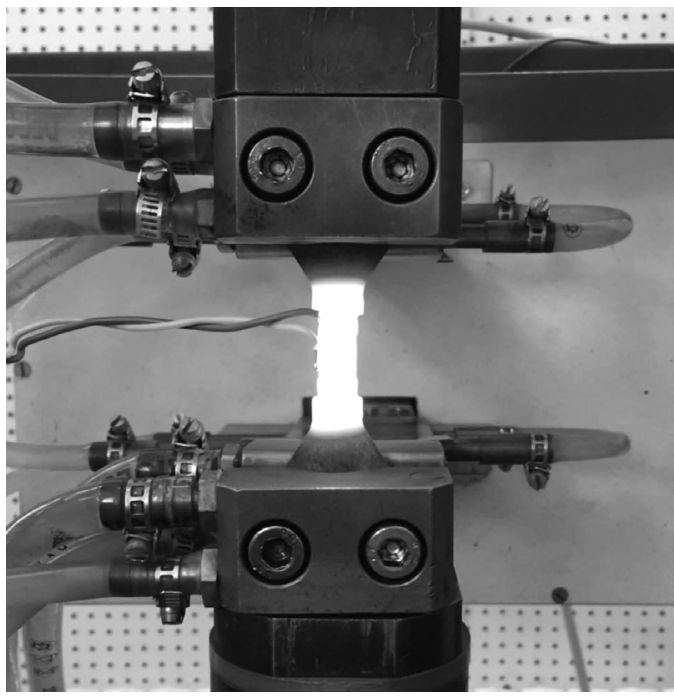

Figure 6: Treatment with a thermomechanical simulator

mechanical simulator also allows a combination of tensile and compressive deformation, thus accumulating a high plastic deformation (and a high dislocation density) in a specimen.

\subsection{Testing programme}

The testing programme involved two different groups. The tests are summarized in Table 2.

Tests in group A were carried out to investigate the thermomechanical behaviour of different materials (1-8) at different temperatures, looking at a single tensile and compression loading with a constant strain rate of $1 \mathrm{~s}^{-1}$ (Figure 7). In order to give a clearer comparison of the results, only the results at room temperature (RT), (800, 1000 and 1200) ${ }^{\circ} \mathrm{C}$ are presented.

Tests in group B were performed to investigate the effects of the holding time at $1000{ }^{\circ} \mathrm{C}$ and the deformation percentage on materials 7 and 8 with the type- 2 specimen shape (Figure 2b). The specimen was designed in order to apply four different deformations $(5,8$, 20 and $50 \%$ ) at the same time (Figure 8), and subsequently one specimen from each material was quenched in water for immediate cooling and the rest were kept in the furnace at three different holding times $(10,20,40) \mathrm{h}$, after which they were cooled slowly to room temperature.

Treatment No. 1 was designed to apply three different single deformations on each sample at different temperatures. The specimen is first heated up to the

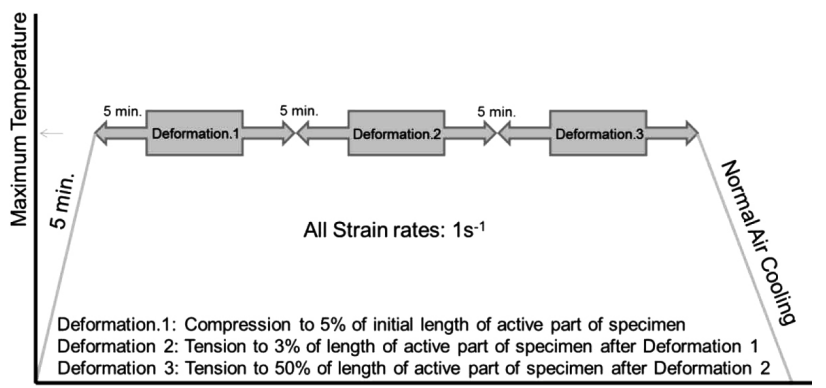

Figure 7: Treatment No. 1

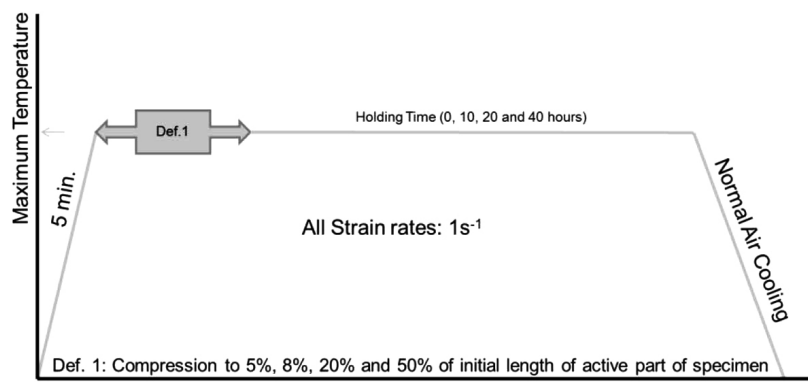

Figure 8: Treatment No. 2

desired temperature in $5 \mathrm{~min}$ and is then held for another five minutes. Immediately after these $10 \mathrm{~min}$, the first deformation (5\% compression) is applied to the specimen and then the temperature is held for another five minutes. The second deformation (3\% tension) is applied immediately after $5 \mathrm{~min}$ and again the temperature is held for five minutes and after that the last deformation (50\% tension) is applied and the specimen is left to cool down to room temperature.

Treatment No. 2 was designed to apply four different deformations $(5,8,20$ and 50) \% at the same time on a specimen. First, the specimen is heated to the desired temperature in 5 minutes and immediately after that, the deformation is applied. The temperature is kept for different holding times $(0,10,20,40) \mathrm{h}$ and then the specimen is left to cool down to room temperature.

\section{RESULTS AND DISCUSSION}

\subsection{Test group A}

Figure 9 shows the stress-strain curves for all the materials at different temperatures, with $5 \%$ compression, corresponding to Treatment No. 1. Material 2 exhibits better strength at $30{ }^{\circ} \mathrm{C}$ (almost $500 \mathrm{MPa}$ ) and $800{ }^{\circ} \mathrm{C}$ (almost $300 \mathrm{MPa}$ ); at $1200{ }^{\circ} \mathrm{C}$, material 1 still

Table 2: Parameters of the testing programme

\begin{tabular}{|c|c|c|c|c|c|c|}
\hline Test group & $\begin{array}{l}\text { Material } \\
\text { No. }\end{array}$ & $\begin{array}{l}\text { Treatment } \\
\text { No. }\end{array}$ & $\begin{array}{l}\text { Holding } \\
\text { time }(\mathrm{h})\end{array}$ & $\begin{array}{c}\text { Maximum temperature } \\
\left({ }^{\circ} \mathrm{C}\right)\end{array}$ & $\begin{array}{l}\text { Number of } \\
\text { tests }\end{array}$ & Purpose of tests \\
\hline A & $\begin{array}{l}1,2,3,4,5 \\
6,7,8\end{array}$ & 1 & - & $\begin{array}{l}\text { 1200, 1100, 1000, 900, } \\
\text { 800, RT }\end{array}$ & 48 & $\begin{array}{c}\text { Investigation of } \\
\text { thermomechanical behaviour }\end{array}$ \\
\hline B & 7,8 & 2 & $\begin{array}{l}0,10 \\
20,40\end{array}$ & 1000 & 40 & Investigation of grain-size growth \\
\hline
\end{tabular}


shows better strength (almost $60 \mathrm{MPa}$ ), but not very different from material 2 (almost $50 \mathrm{Mpa}$ ). It seems that the difference in the compression strength between these two materials is almost $37 \%$ at RT; however, this difference increased to $137 \%$ at $800{ }^{\circ} \mathrm{C}$. On the other hand, all the materials have almost the same elastic modulus and none of them fails at the $5 \%$ compression. However, material 4 shows a strange behaviour at $800{ }^{\circ} \mathrm{C}$. The microstructure analysis shows that this occurred because of an inhomogeneous formation of the particles in the specimen.

The hot-working behaviour of alloys is generally reflected by flow curves, which are a direct consequence of microstructural changes: the nucleation and growth of new grains, dynamic recrystallization (DRX), the generation of dislocations, work hardening (WH), the rearrangement of dislocations and their dynamic recovery (DRV). In deformed materials, DRX seems to be the prominent softening mechanism at high temperatures. DRX occurs during the straining of metals at high temperatures, characterized by a nucleation of lowdislocation-density grains and their posterior growth, producing a homogeneous grain structure when dynamic equilibrium is reached. Material 4 showed a strange curve shape at $800{ }^{\circ} \mathrm{C}$. The test was repeated several times and similar behaviour was observed each time. It was concluded that this happens because of the inhomogeneity of the microstructure of this material.

Figure 10 shows the stress-strain curves at different temperatures corresponding to the $3 \%$ tension of Treatment No. 1. As can be seen in Figure 10, material 2 shows a higher strength at $30{ }^{\circ} \mathrm{C}$ (almost $650 \mathrm{MPa}$ ) and $800{ }^{\circ} \mathrm{C}$ (almost $270 \mathrm{MPa}$ ), but at $1200{ }^{\circ} \mathrm{C}$, material 1 again shows a better strength (almost $65 \mathrm{MPa}$ ). This value was $35 \%$ lower when the temperature was increased. In Figure 10, the strain at the maximum tension is almost $2 \%$ at RT (Figure 10a), then it increases to almost $3 \%$ at $800{ }^{\circ} \mathrm{C}$ (Figure 10b); however, it decreases to almost $1 \%$ at $1200{ }^{\circ} \mathrm{C}$ (Figure 10c). All the
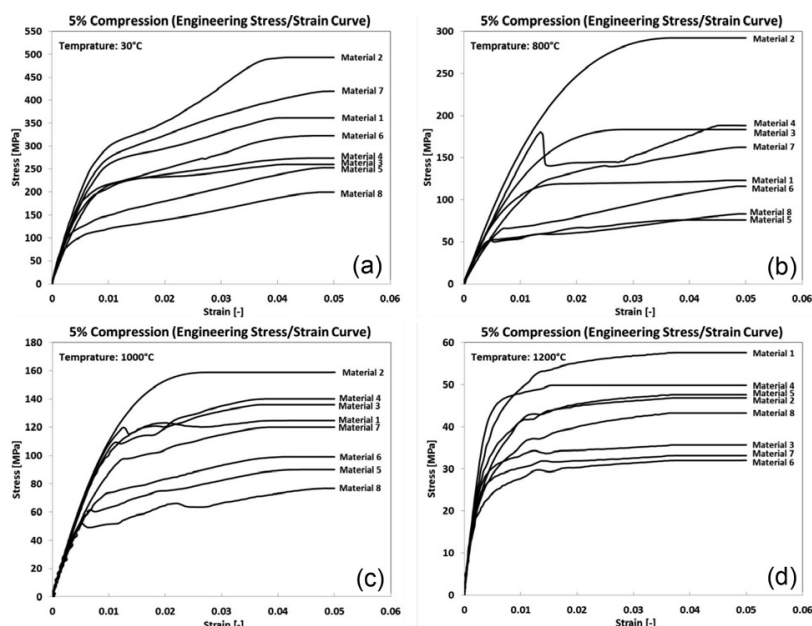

Figure 9: Stress-strain curves (5\% compression) for: a) RT, b) $800{ }^{\circ} \mathrm{C}$, c) $1000{ }^{\circ} \mathrm{C}$, d) $1200{ }^{\circ} \mathrm{C}$ materials have almost the same elastic modulus and none of them failed at the $3 \%$ deformation. The yield stress and the shape of the flow curves are sensitive to temperature. Comparing all these curves, it is found that decreasing the deformation temperature increases the yield-stress level. In other words, it prevents softening due to dynamic recrystallization (DRX) and dynamic recovery (DRV) and allows the deformed metals to exhibit work hardening (WH). For every curve, after a rapid increase in the stress to the peak value, the flow stress decreases monotonically towards a steady-state regime with a varying softening rate, which typically indicates the onset of DRX, Figure 10c.

Figure 11 shows the stress-strain curves at different temperatures for the $50 \%$ tension of Treatment No. 1 . All eight materials failed at RT, but only four materials failed below the $50 \%$ tension at higher temperatures. Material 2 failed at the $34 \%$ strain, materials 4 and 5 failed at around $45 \%$ strain and material 8 failed at around $50 \%$ at $800{ }^{\circ} \mathrm{C}$. At $1200{ }^{\circ} \mathrm{C}$, only material 1 failed at $41 \%$ and material 2 failed at the $45 \%$ strain. From these curves, it can also be seen that the stress evolution with strain exhibits three distinct stages.

Work hardening $(\mathrm{WH})$ predominates in the first stage and causes dislocations to polygonise into stable subgrains. The flow stress exhibits a rapid increase with the increasing strain up to the critical value. Then DRX occurs due to a large difference in the dislocation density within subgrains or grains. When the critical driving force of DRX is attained, new grains are nucleated along the grain boundaries, deformation bands and dislocations, resulting in the formation of equiaxed DRX grains.

In the second stage, the flow stress exhibits a smaller and smaller increase until the peak value, or an inflection of the work-hardening rate is reached. This shows that thermal softening becomes more and more important due to DRX and dynamic recovery (DRV) and it exceeds WH.

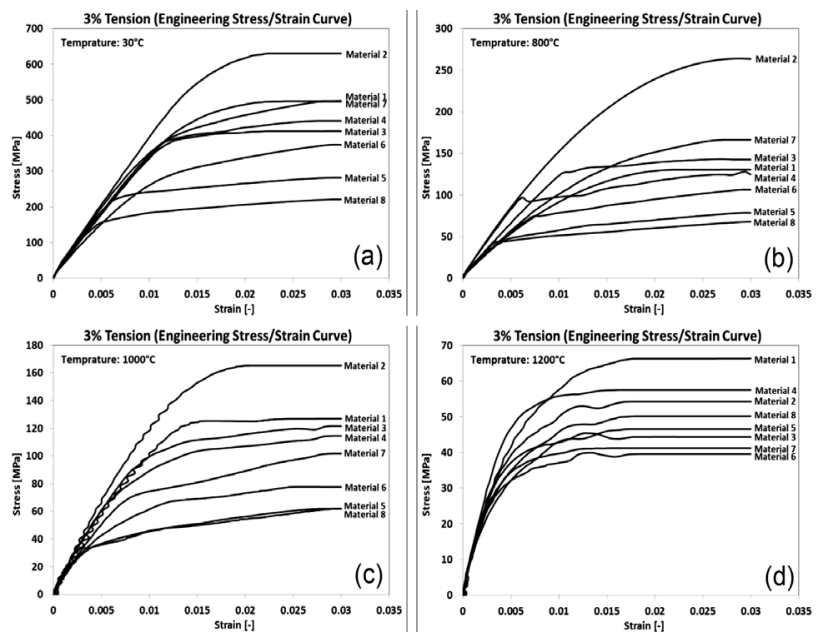

Figure 10: Stress-strain curves ( $3 \%$ tension) for: a) RT, b) $800{ }^{\circ} \mathrm{C}$, c) $1000{ }^{\circ} \mathrm{C}$, d) $1200{ }^{\circ} \mathrm{C}$ 
O. KHALAJ et al.: INFLUENCE OF THERMOMECHANICAL TREATMENT ON THE GRAIN-GROWTH BEHAVIOUR ...
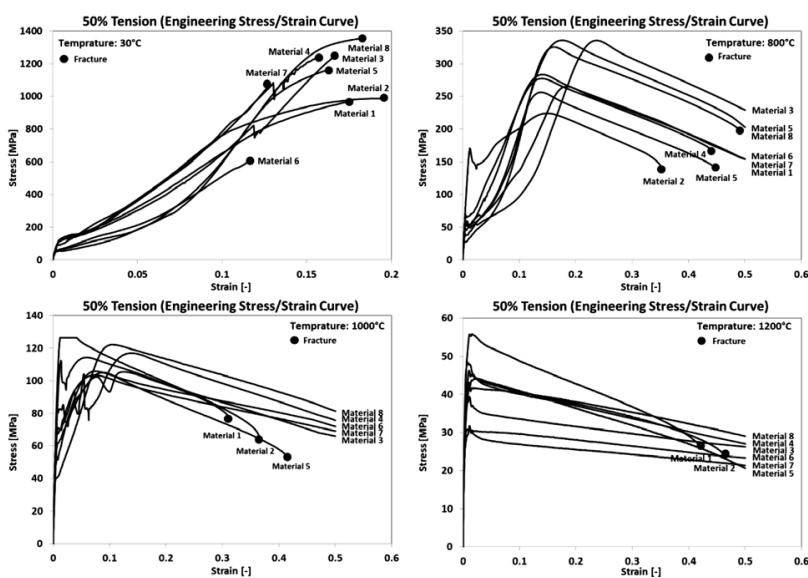

Figure 11: Stress-strain curves (50\% tension) for: a) RT, b) $800{ }^{\circ} \mathrm{C}$, c) $1000^{\circ} \mathrm{C}$, d) $1200{ }^{\circ} \mathrm{C}$

In the third stage, three types of curves can be recognized:

- A gradual decrease to a steady state with DRX softening (Figure 11c).

- A continuous increase with significant work-hardening (Figure 11a).

- A continuous decrease with significant DRX softening (Figure 11b).
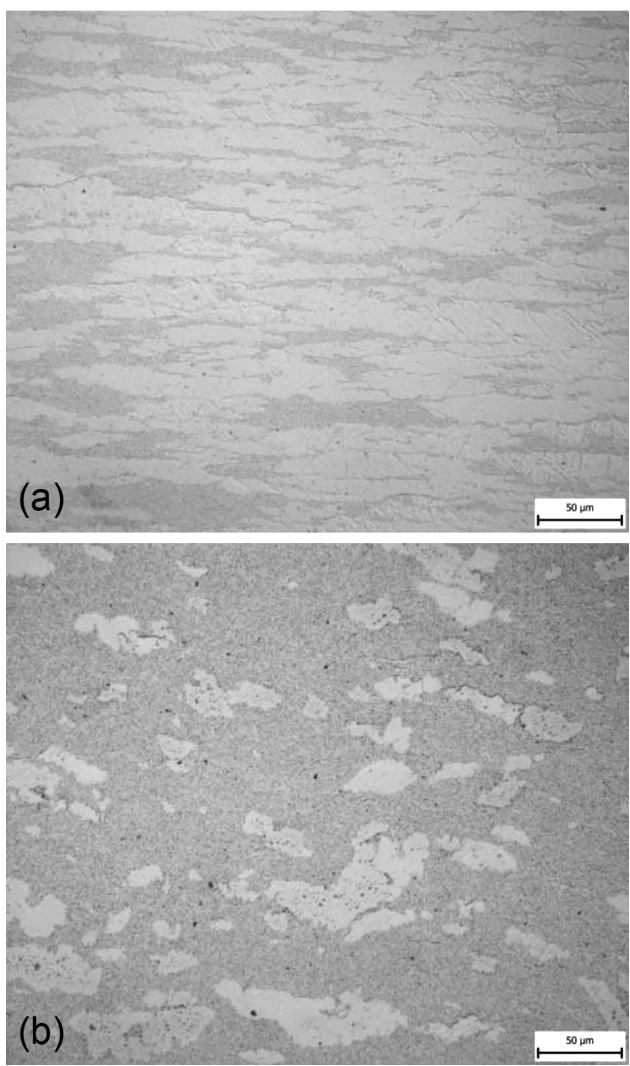

Figure 12: Microstructure for material 7 without annealing a) without deformation, b) with $50 \%$ deformation

\subsection{Test group $B$}

Figures 12 to 19 show the microstructures of materials 7 and 8 without deformation and with the $50 \%$ deformation at different annealing times of $(0,10,20$ and 40) $\mathrm{h}$ at $1000{ }^{\circ} \mathrm{C}$. It can be seen that by increasing the annealing time, the number of low-angle grain boundaries $\left(<15^{\circ}\right)$ decreased. This indicates that recrystallization does not occur at the zones with shorter annealing times (Figure 12a). A few banding zones with a high density of low-angle grain boundaries are observed in Figures 14a and 16a showing that recrystallization occurs in most zones. Figure 18a shows that the banding zones with a high density of low-angle grain boundaries cannot be observed, indicating that almost completely recrystallized ferrite grains can be obtained after annealing at $1000{ }^{\circ} \mathrm{C}$ for $40 \mathrm{~h}$.

Similar results were achieved for the rest of the specimens; however, there is a major difference between the microstructures. Material 7 is partially recrystallized, but material 8 retained fine grains. Both materials were prepared using the same procedure, but with different rolling pressures during the hot-rolling process. During the rolling process, a specimen passes through different stages. In the first stage of rolling, the material is under a considerable mechanical stress, resulting from an internally balanced elastic strain. This elastic strain is

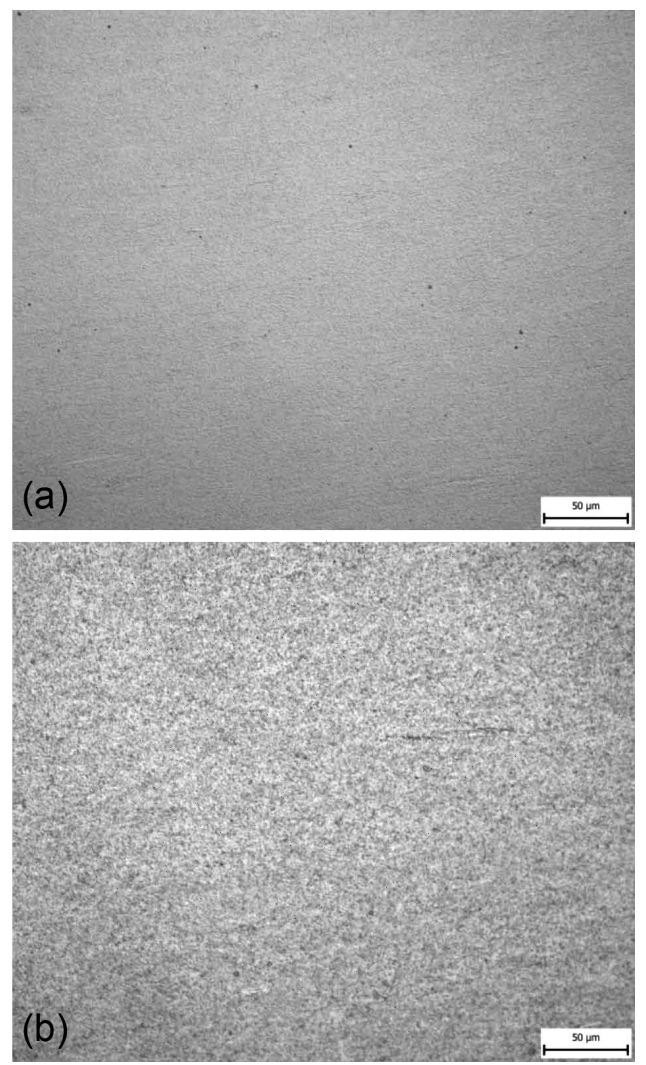

Figure 13: Microstructure of material 8 without annealing: a) without deformation, b) with $50 \%$ deformation 


\section{MATERIALI IN TEHNOLOGIJE/MATERIALS AND TECHNOLOGY (1967-2017) - 50 LET/50 YEARS}

O. KHALAJ et al.: INFLUENCE OF THERMOMECHANICAL TREATMENT ON THE GRAIN-GROWTH BEHAVIOUR ...
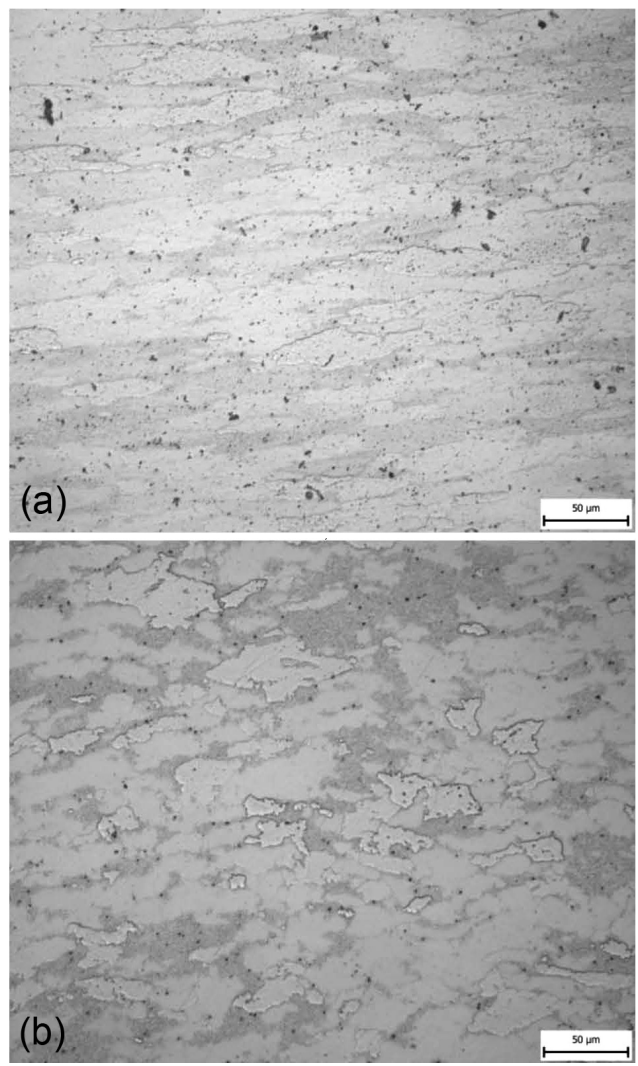

Figure 14: Microstructure for material 7 after $10 \mathrm{~h}$ annealing: a) without deformation, b) with $50 \%$ deformation
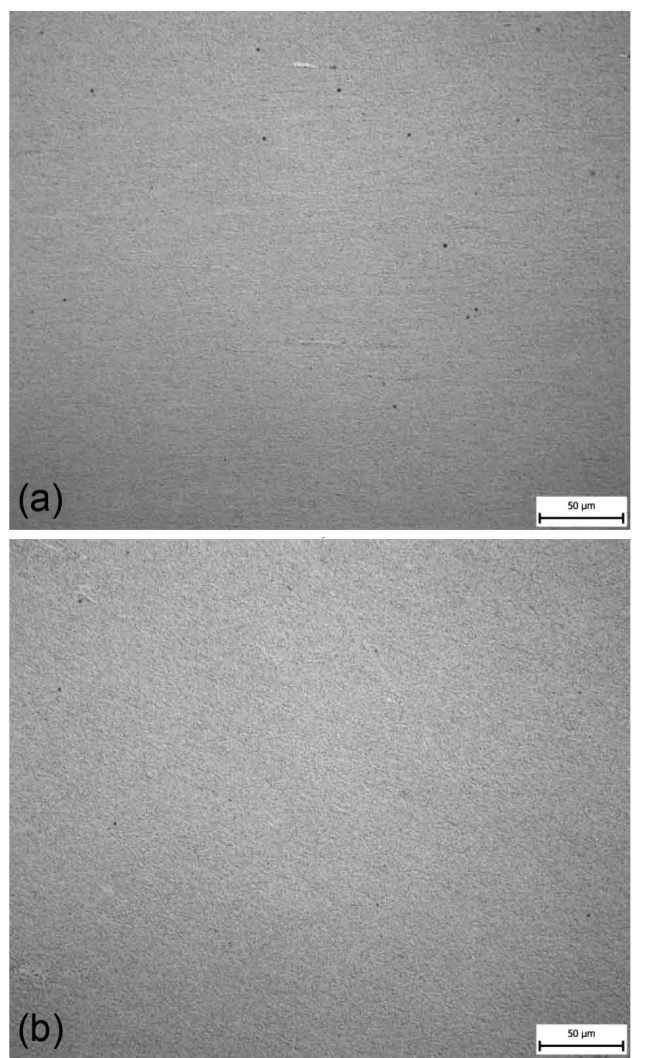

Figure 15: Microstructure for material 8 after $10 \mathrm{~h}$ annealing: a) without deformation, b) with $50 \%$ deformation
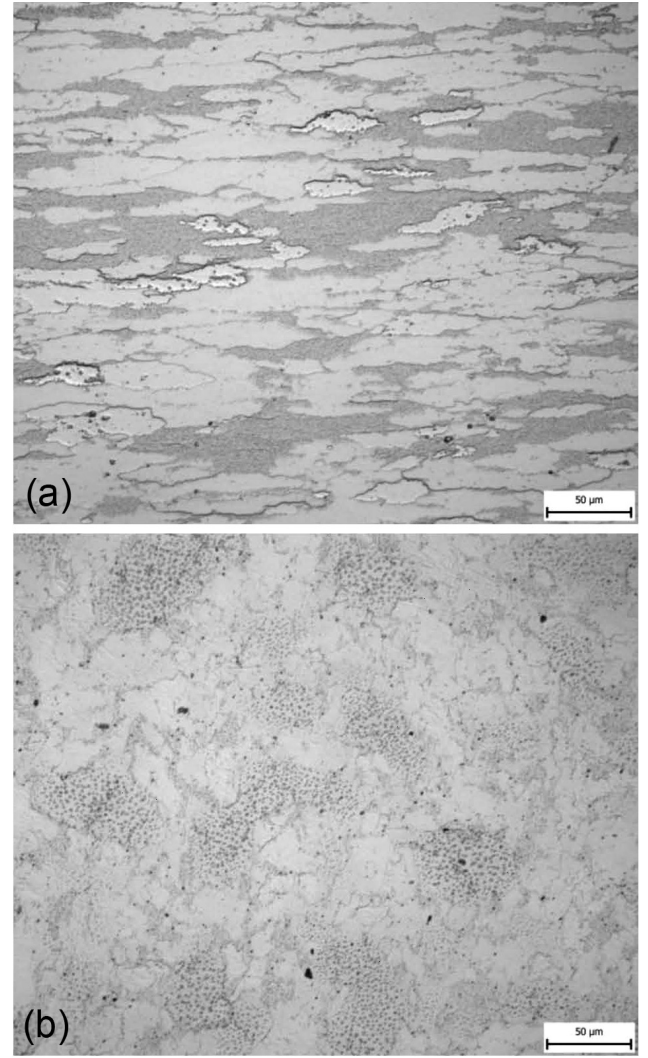

Figure 16: Microstructure for material 7 with $20 \mathrm{~h}$ annealing: a) without deformation, b) with $50 \%$ deformation

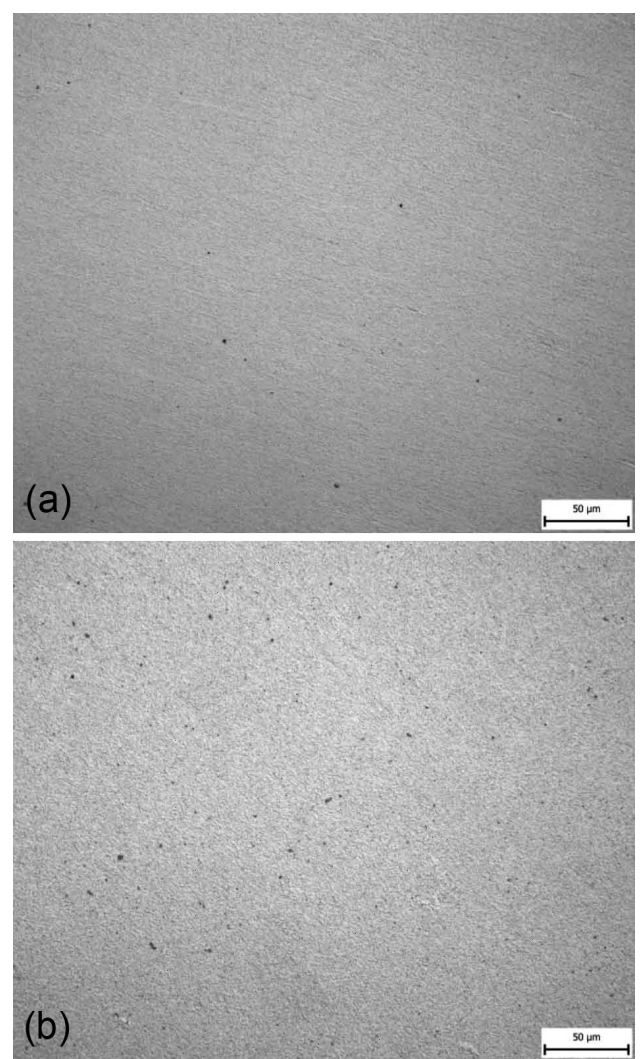

Figure 17: Microstructure for material $8 \mathrm{~h}$ with $20 \mathrm{~h}$ annealing: a) without deformation, b) with $50 \%$ deformation 
O. KHALAJ et al.: INFLUENCE OF THERMOMECHANICAL TREATMENT ON THE GRAIN-GROWTH BEHAVIOUR ...

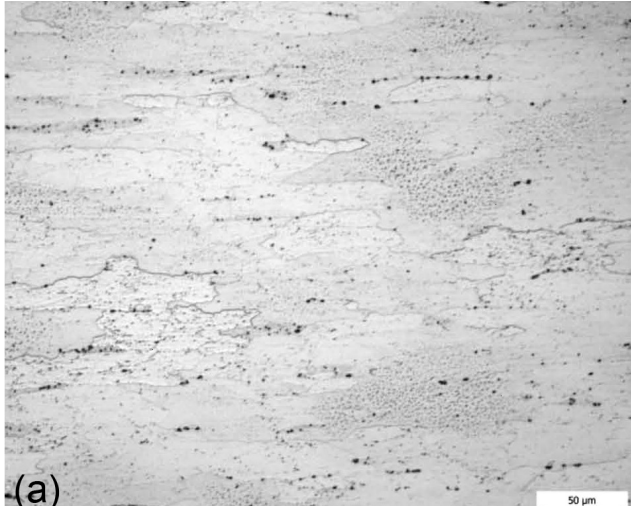

(a)

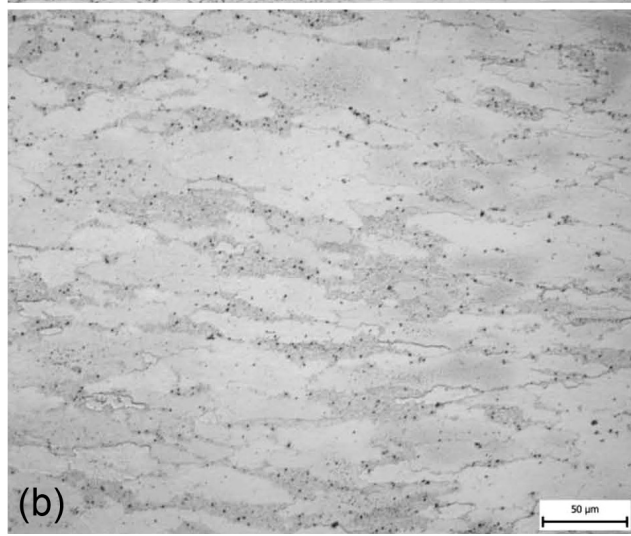

Figure 18: Microstructure for material 7 with $40 \mathrm{~h}$ annealing: a) without deformation, b) with $50 \%$ deformation

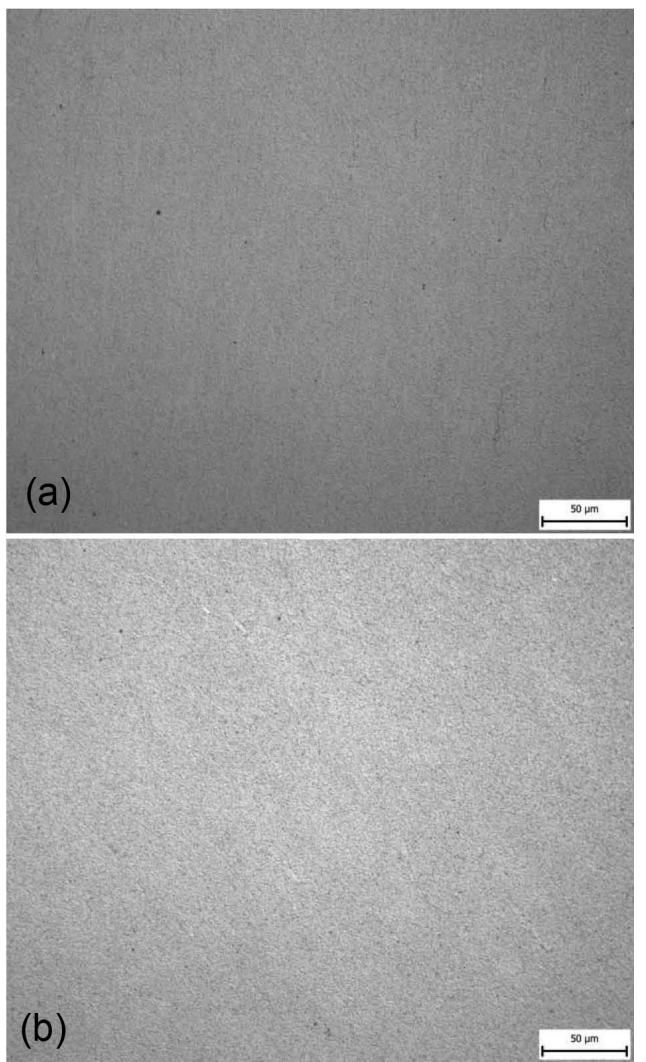

Figure 19: Microstructure for material $8 \mathrm{~h}$ with $40 \mathrm{~h}$ annealing: a) without deformation, b) with $50 \%$ deformation added to the jamming of the dislocation, which occurred during cold forming.

In Figures 12, 14, 16 and 18, there is a visible alternation in the distorted shape of the cold-work crystals at the stress-relief stage (Figures 12a, 14a, 16a and 18a). In this stage, new crystals begin to grow in the deformed crystals. In the next stage (Figures 12b, 14b, 16b and $18 \mathrm{~b})$, the small crystals that formed in the previous stage gradually grow into bigger crystals by absorbing each other in the cannibal fashion, thus making the structure relatively coarse grained.

Figures 12 to 19 show that with the increasing strain, a cellblock structure gradually develops and the sizes of the cellblocks and the cells decrease. In other words, in material 7 (Figures 12, 14, 16 and 18), there is a great transformation. It can be seen that with the increasing strain, there are changes in the spacing of the dense dislocation walls and micro-bands (DDW-MBs) and in the cell size. It is seen that after a $50 \%$ deformation, the spacing of the DDW-MBs decreased to almost $50 \mu \mathrm{m}$, close to the cell size. In addition, the rate of the decrease in spacing with the increasing strains is much larger for geometrically necessary boundaries (GNBs) than for incidental dislocation boundaries (IDBs). However, in material 8 (Figures 13, 15, 17 and 19), there was no serious transformation and the structure still shows ferrite and pearlite. The grain size is relatively similar for both deformations. The grain boundaries can no longer be seen clearly, as the ferrite precipitated with the pearlite, creating a grey shade instead of a clear black-andwhite contrast.

Figure 20 gives an overview of the grain sizes of materials 7 and 8 with different deformations and annealing times. It can be seen that as material 7 is almost recrystallized, it has a bigger grain size than material 8. From Figure 20 it is clear that by increasing

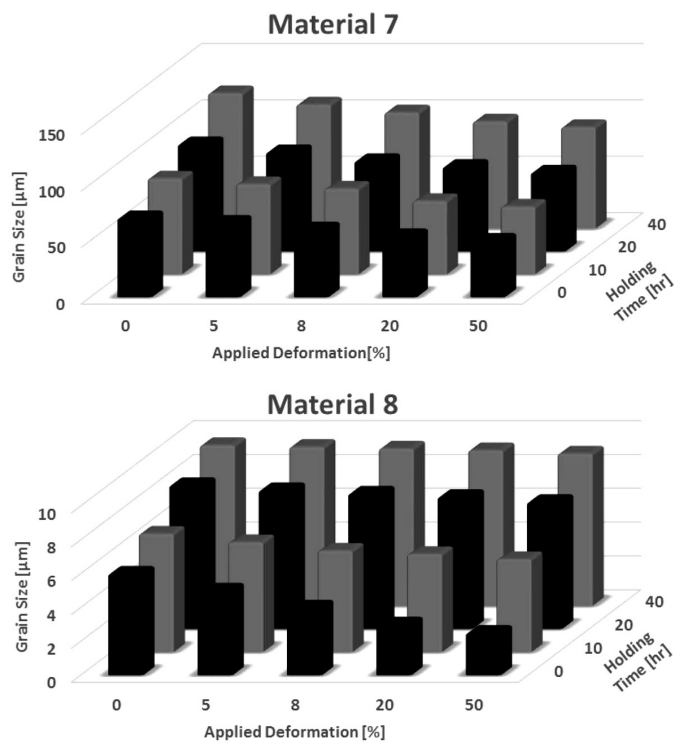

Figure 20: Grain size for: a) material 7, b) material 8 
the annealing time, the grain size increases significantly for material 7 (Figure 20a), however the rate of increase in grain size is lower for material 8 (Figure 20b). The grain size reached almost $120 \mu \mathrm{m}$ after 40 hours annealing without any deformation in material 7 , while the grains in material 8 reached almost $10 \mu \mathrm{m}$ under the same conditions. On the other hand, by increasing the applied deformation, the grain size of both materials decreased smoothly. Material 7 reached $50 \mu \mathrm{m}$ by applying $50 \%$ deformation without annealing while material 8 reached almost $3 \mu \mathrm{m}$ under the same conditions. One can thus conclude that the stability of grain microstructure can be significantly influenced by the processing. The analysis of the reasons for this will be the topic of future work by the team.

\section{CONCLUSIONS}

If you mean that why we didn't present the microstructe of material 1-6, because all the materials except 7 has fine microstructure similar to material 8 , that is why we decide to present only the microstructure results from material 7 and 8 and compare them in this view point.

This paper outlines the influence of thermomechanical treatment on the grain growth of new Fe-Al based alloys with fine $\mathrm{Al}_{2} \mathrm{O}_{3}$ precipitates. Eight materials differing in the amount and size of the oxides embedded in the ferritic matrix were tested under different conditions. The advantages of all the materials are their low-cost, simplicity of preparation and significant mechanical properties together with micro structures, due to the Fe-Al based ferritic matrix of the ODS alloy. The results from material 1-6 described in the relevant section (3.1. test group A) and the results from material 7-8 in case of microstructure described in section (3.2 test group B). As all the materials except 7 has fine microstructure similar to material 8 , only the microstructure results from material 7 and 8 compared in this view point. It can be concluded that in general the oxide dispersion significantly strengthens the material. However, the typical form of the flow curve with DRX softening, including a single peak followed by a steady state flow as a plateau, is more recognizable at high temperatures than at low temperatures. This is because at high temperatures the DRX softening compensates for the work hardening $(\mathrm{WH})$, and both the peak stress and the onset of steady state flow are therefore shifted to lower strain levels. The characteristics of softening flow behaviour coupled with DRX were investigated for eight materials and can be summarized as follows:

Decreasing deformation temperature causes the flow stress level to increase. In other words, it prevents the occurrence of softening due to DRX and dynamic recovery (DRV) and causes the deformed metals to exhibit work hardening (WH).

For every curve, after a rapid increase in the stress to a peak value, the flow stress decreases monotonically towards a steady state regime (a steady state flow as a plateau due to DRX softening is more recognizable at higher temperatures). A varying softening rate typically indicates the onset of DRX, and the stress evolution with strain exhibits three distinct stages.

At higher temperatures, a higher DRX softening compensates the $\mathrm{WH}$, and both the peak stress and the onset of steady state flow are therefore shifted to lower strain levels.

The elastic part of the total strain amplitude is always higher than the plastic part in all specimens tested, even for the highest total strain amplitudes of $15 \%$. This is further confirmation of the strong strengthening effect of oxide particles.

Material 7 is more crystallised than material 8. Thus, it has a larger grain size compared to the fine grains of material 8.

\section{Acknowledgements}

This paper includes results from projects 14-24252S Preparation and Optimization of Creep Resistant Submicron-Structured Composite with Fe-Al Matrix and $\mathrm{Al}_{2} \mathrm{O}_{3}$ Particles subsidised by the Czech Science Foundation.

\section{REFERENCES}

${ }^{1}$ M. Mohan, R. Subramanian, Z. Alam, P. C. Angelo, Evaluation of the Mechanical Properties OF A Hot Isostatically Pressed YttriaDispersed Nickel-Based Superalloy, Mater. Tehnol., 48 (2014) 6, 899-904

${ }^{2}$ W. Quadakkers, Oxidation of ODS alloys, Journal de Physique IV, 03 (1993) C9, 177-186, doi:10.1051/jp4:1993916

${ }^{3}$ F. Pedraza, Low Energy-High Flux Nitridation of Metal Alloys: Mechanisms, Microstructures and High Temperatures Oxidation Behaviour, Mater. Tehnol., 42 (2008) 4, 157-169

${ }^{4}$ O. Khalaj, B. Mašek, H. Jirkova, A. Ronesova, J. Svoboda, Investigation on New Creep and Oxidation Resistant Materials, Mater. Tehnol., 49 (2015) 4, 173-179, doi:10.17222/mit.2014.210

${ }^{5}$ F. D. Fischer, J. Svoboda, P. Fratzl, A thermodynamic approach to grain growth and coarsening, Journal of Philosophical Magazine, 83 (2003) 9, 1075-1093, doi:10.1080/0141861031000068966

${ }^{6}$ M. J. Alinger, G. R. Odette, D. T. Hoelzer, On the role of alloy composition and processing parameters in nanocluster formation and dispersion strengthening in nanostuctured ferritic alloys, Acta Material, 57 (2009) 2, 392-406, doi:10.1016/j.actamat.2008.09.025

${ }^{7}$ P. Unifantowicz, Z. Oksiuta, P. Olier, Y. de Carlan, N. Baluc, Microstructure and mechanical properties of an ODS RAF steel fabricated by hot extrusion or hot isostatic pressing, Fusion Engineering and Design, 86 (2011), 2413-2416, doi:10.1016/j.fusengdes. 2011.01 .022

${ }^{8}$ M. A. Auger, V. de Castro, T. Leguey, A. Muñoz, R. Pareja, Microstructure and mechanical behavior of ODS and non-ODS Fe-14Cr model alloys produced by spark plasma sintering, Journal of Nuclear Materials, 436 (2013) 5, 68-75, doi:10.1016/j.jnucmat.2013.01.331

${ }^{9}$ M. Kos, J. Ferčec, M. Brunčko, R. Rudolf, I. Anžel, Pressing of Partially Oxide-Dispersion-Strenghtened Copper using the ECAP Process, Mater. Tehnol., 48 (2014) 3, 379-384, UDK 621.777.2:669.35'71

${ }^{10}$ B. Mašek, O. Khalaj, Z. Nový, T. Kubina, H. Jirkova, J. Svoboda, C. Stádler, Behaviour of New ODS Alloys under Single and Multiple Deformation, Mater. Tehnol., 50 (2016) 6, 891-898, doi:10.17222/ mit.2015.156 


\section{MATERIALI IN TEHNOLOGIJE/MATERIALS AND TECHNOLOGY (1967-2017) - 50 LET/50 YEARS}

O. KHALAJ et al.: INFLUENCE OF THERMOMECHANICAL TREATMENT ON THE GRAIN-GROWTH BEHAVIOUR ...

${ }^{11}$ Marmy, P., Kruml, T., Low cycle fatigue of Eurofer 97, Journal of Nuclear Materials, 377 (2008) 1, 52-58, doi:10.1016/j.jnucmat. 2008.02.054

${ }^{12}$ M. Mišović, N. Tadić, M. Jaćimović, M. Janjić, Deformations and Velocities during the Cold Rolling of Aluminium Alloys, Mater. Tehnol., 50 (2016) 1, 59-67, doi:10.17222/mit.2014.250

${ }^{13}$ A. Grajcar, Microstructure Evolution of Advanced High-Strength Trip-Aided Bainitic Steel, Mater. Tehnol., 49 (2015) 5, 715-720, doi:10.17222/mit.2014.154

${ }^{14}$ B. Šuštaršič, I. Paulin, M. Godec, S. Glodež, M. Šori, J. Flasker, A. Korošec, S. Kores, G. Abramovič, DSC/TG of Al-based Alloyed Powders for P/M Applications, Mater. Tehnol., 48 (2014) 4, 439-450

${ }^{15}$ F. Tehovnik, J. Burja, B. Podgornik, M. Godec, F. Vode, Microstructural evolution of Inconel 625 during hot rolling, Mater. Tehnol., 49 (2015) 5, 899-904, doi:10.17222/mit.2015.274 